\title{
Editorial: Occupational Devotion and Lifestyle Entrepreneurship: Doing what we love, loving what we do!
}

\author{
Richard Keith Wright ${ }^{1} \cdot$ Richard Mitchell ${ }^{2}$
}

Received: 17 December 2021 / Accepted: 18 December 2021 / Published online: 9 February 2022

(c) The Author(s), under exclusive licence to Springer Nature Switzerland AG 2022

\section{Tuesday 21 August 2001, about 9:30am (Emergency Department, Austin Hospital, Melbourne)}

... What if I am paralysed?

... What if Carleen has to care for me for the rest of my life?

... How could I have been so selfish to do this to her?

... Why now when she is going to need me the most?

I grip Carleen's hand as tight as I can.

I don't want to let go!

I never want to let go of her ever again!

A last-minute decision to take a shortcut while riding to work and an inattentive truck driver came together in a split second. It was a second that very nearly killed Richard Mitchell. As it was, his life was shattered, his hopes and dreams in tatters, his body broken. He was facing more than a dozen surgeries, six months away from his dream job and years of recovery and rehab.

While their worlds hadn't yet come together, Richard Mitchell (RM) and Richard Keith Wright (RKW) were soon to have the very visceral shared experience of September $11^{\text {th }} 2001$. As you'll soon discover, RKW was just starting out on his journey, while RM had been in his dream job teaching wine, tourism and hospitality for just six months. He had found his passion and was utterly devoted to it.

Stebbins $(2014, \mathrm{p}, 4)$ defines 'devotee work' as 'an activity in which participants feel a powerful devotion... to an occupation that they are proud to be in". The foundations for this special edition pre-date COVID-19 by a couple of decades. The ongoing global pandemic, however, caused RM and RKW (and a billion others) to

Richard Keith Wright

richard.wright@aut.ac.nz

Richard Mitchell

richard.mitchell@op.ac.nz

1 Sports Performance Research Institute (AUT), Dunedin, New Zealand

2 College of Work-based Learning (Otago Polytechnic), Dunedin, New Zealand 
stop what they were doing and to re-assess the origins of their occupational devotion. What follows is a co-constructed autobiographical narrative produced with the intention of bringing you into the social worlds of the two minds behind this special edition. Once you know where it's come from, you will hopefully find it easier to see the new knowledge and understanding created as a result of our active sociological imagination (Wright, 2019).

RM's accident started him on a serious leisure journey that drew on his obsession with everything sport. It created a desire for him to (re)take control of his life after several years of depression. What started as jogging to get fit in 2008, quickly escalated to swimming, biking and running in excess of 6,000 kms. In the February of 2009, RM and RKW lined up together in Central Otago, New Zealand, on the start line of a two-day $152 \mathrm{~km}$ duathlon. Two years later, RM completed his first irondistance triathlon. A couple of months later, RKW, now living 18,955 km away from RM in Leeds, England, completed his first marathon.

By 2011, RM and RKW had known each other for more than seven years. RM had supervised RKW's masters and PhD. RKW's unashamedly self-indulgent autoethnographic doctorate, completed between 2006 and 2010, influenced them both profoundly, inspiring RM's own foray into heartful, creative non-fiction (Wright, 2017). The opening excerpts presented above have been extracted from RM's personal blog. It was informed by his reading of everything from medical journals to the anthropology of running and Marquis de Sade. For both RM and RKW alike, it's construction and subsequent consumption was cathectic, therapeutic and transformational.

RKW loved how RM articulated his lived experiences in a manner that he knew would not only help his recovery, but also that of others. Unlike RKW, RM had made a conscious decision that his serious leisure pursuit would not bleed into his occupation (something that had already happened with food and wine). Sport was to remain separate from his work. For RKW, however, that was not an option, even when his job was teaching tourism and event management (those socially-constructed boundaries had been removed many, many years previously).

Fast forward to 2021 and, with a little help from RKW, RM was able to see how his own occupational devotion had effectively morphed from a focus on his workrelated serious leisure pursuits (wine and food) to a passion for unlocking the same feeling in others. Since 2011, he has been using the power of autoethnography on a daily basis, largely as a tool to help experienced and emerging chefs discover their passion for cooking (Mitchell et al., 2020).

\section{Sunday 12 September 2021, about 2.30am (Auckland, New Zealand)}

In the early hours of Sunday September 12th, 2021, RKW found himself in an alltoo-familiar position. It was the middle of the night and he was unable to sleep. The twentieth anniversary of 9/11 had fallen on day 25 of a Covid-19 lockdown that started on August $15^{\text {th }}$ and ended on December $4^{\text {th }}$. As with the shorter lockdowns 
experienced in 2020 and 2021, RKW and his wife were required to balance the wants and needs of their two employers with those of their two young children.

Twenty years earlier, as RM's broken body lay in a Melbourne hospital bed, RKW was living the dream on the other side of the world. He had spent his summer at home, working five days a week for the Cambridge Tourist Information Centre (TIC). For RKW, this wasn't a job, it was more of a calling (Duffy et al, 2018). It gave his life meaning, a sense of purpose and self-fulfilment. He loved helping people. He loved meeting new people. He loved learning and sharing stories about the history of his home town.

RKW's first day at the TIC was the week after he returned home having finished the first year at the University of Brighton's School of Service Sector Management. Months earlier, during the easter break, he had secured himself the twelve-month internship that would allow him to live at home and gain some industry experience to compliment his tourism management studies. Although the work was repetitive (supplying maps, selling and taking tours, booking accommodation, selling souvenirs, giving directions, offering personal recommendations etc.), every day was different.

In June 2002, the week after RKW completed his undergraduate degree, he was back behind the counter of the Cambridge TIC, doing a job that he saw himself doing for many years to come. In 2003, however, RKW was forced to think again. An unforeseen restructure forced many of his friends/colleagues into early retirement or, worse, unemployment. Rather than accept the new role being offered to him, RKW decided that his future no longer lay within the TIC, or indeed in Cambridge. He handed in his resignation.

On the $11^{\text {th }}$ of September 2003, having spoken to his family and his Honours dissertation supervisor, a New Zealander named Brent Ritchie, RKW submitted an application to study a Masters of Tourism at the University of Otago, New Zealand. Whilst many of his friends had travelled the world after completing their studies, RKW had gone straight from full-time study into full-time employment at the TIC. RKW decided to combine his overseas travel with the acquisition of a postgraduate qualification that would help him find a new role upon his return to England.

On the $4^{\text {th }}$ February, 2004, having seen out his notice period and enjoy one last winter Christmas, RKW said an emotional farewell to his family and friends, including his former TIC colleagues, and boarded a Boeing 747 at London Heathrow Airport bound for Auckland, New Zealand. His final destination was the City of Dunedin, the university town in which Brent Richie had recently completed his $\mathrm{PhD}$. $\mathrm{He}$ spent the entirety of February $5^{\text {th }} 2004$ flying over two oceans and the North American continent and arrived in his new home on Waitangi Day, a New Zealand national holiday. He spent much of his first year, watching cricket and rugby, playing football and finding reasons to travel around the country. He made many new friends, RM included, and fell head over heels in love (with the people and the places that he visited).

The University of Otago's Department of Tourism was full of academics from all over the world, all of whom were undertaking exploratory research on subjects that were clearly very close to their heart. RM's passion, for example, was wine 
and food. Another Lecturer, for whom RKW agreed to do some tutoring, was into hunting and fishing. Another was really into airports and aeroplanes. Just as Brent Ritchie had shared his stories of New Zealand to RKW and his classmates at the University of Brighton, RKW was now standing at the front of a classroom sharing his own stories of working in the Cambridge TIC.

In 2005, RKW discovered sports tourism, a form of niche tourism with strong connections to the theories of social identity and serious leisure (Green \& Jones, $2005)$. On the $16^{\text {th }}$ of May, RKW's $25^{\text {th }}$ Birthday, he delivered an hour's guest lecture on the motivations of sport events tourists, which included a case study on those travelling to New Zealand that year for the 2005 British and Irish Lions Tour. By the $11^{\text {th }}$ of September, RKW was fully immersed in a sports event tourism study that would, upon its completion, secure him an International PhD Scholarship, two conference papers and three publications. RKW had found his new calling.

Between 2006 and 2009, RM helped RKW to locate and leverage a sociological imagination that he never knew existed (Wright, 2017). During the first half of 2009 , as the final deadline for the submission of his doctoral thesis grew ever closer and the reality of what he had produced began to sink in, RKW applied for three full-time academic positions; one in Auckland, one in Melbourne and one in Leeds, England. Auckland and Melbourne were cities that featured heavily in his sport event tourism teaching and research, which helped ensure that they were high on the list of places that he would be happy to call home. Auckland was also the home of his partner's family. In contrast, Leeds was one of the few cities in England that RKW had never visited. He knew of their football team, but little else.

On the $10^{\text {th }}$ anniversary of the $9 / 11$ attacks, RKW found himself sitting alone in an otherwise empty Carnegie Headingley Stadium. Looking up to his right, he could see the windows of the classroom in which he had spent the morning teaching. To his left, he could see the Rugby Stand in which he had recently completed yet another university qualification (a Postgraduate Certificate in Higher Education). Whilst it wasn't Cambridge, Dunedin, Auckland or Melbourne, he had been in Leeds for a couple of years and it was slowly beginning to feel like a place in which he could be happy. Since his arrival in the September of 2009, RKW had helped his new colleagues within the UK Centre for Events Management launch the UK's first sports event management programme at both an undergraduate and postgraduate level. In 2010, had become a part of a sport tourism research group featuring academics from all over the UK. He was doing what he loved, he was loving what he did.

\section{So where to from here}

In 2018, RKW spent much of his sabbatical exploring the connections between occupational devotion and lifestyle entrepreneurship. The findings of a study completed with a colleague from the School of Sport and Recreation proposed that lifestyle entrepreneurs working in the New Zealand participant-driven sports event sector seek self-fulfilment through the acquisition of social capital and a healthy 
work-life balance (Wright \& Wiersma, 2019). It was during that research study that RKW found himself thinking of the connections between these concepts and the various life/career choices that he had made over the past two decades, including the one that saw him saying an emotional goodbye to friends and family in England in 2004 and 2011.

Although we are both lifestyle driven work devotees (one with wine and food, the other with sports events and tourism), we have both arrived at a place where it is the occupational devotion and the entrepreneurial mindset of others - our students and our peers - that now drives RM and RKW to be the best that we can be. To us, this special issue is a logical outgrowth of where we've come from, where we are right now, but also where we both want to be in the future. As noted earlier, this research output has been twenty years in the making. In 2017, RKW produced and published an equally evocative piece of creative non-fiction in which he paid tribute to those who helped him overcome his imposter syndrome and the nauseating self-doubt that threatened to end an academic career before it had even got started (Wright, 2017). RM was one of those people. As noted above, he provided RKW with the direction, the debate and the discipline needed to turn a childhood obsession into a grown-up profession.

In 2020, around the same time that COVID-19 was deemed a global pandemic, we challenged our peers from within and beyond the realms of leisure studies to produce a something meaningful and memorable. We asked for articles written from the heart and for personal narratives that the authors would be happy to revisit in ten- or twenty-years' time. We encouraged submissions that pushed, if not ignored, some of the professional boundaries found within the academy. In sum, the contributors to this special edition were given the freedom to be/become self-indulgent and self-centred (Wright, 2019).

Before we go any further, we would like to acknowledge the editors and administrators of the International Journal of the Sociology of Leisure for their support and patience during the creation of this edition. We'd also like to thank all the reviewers who offered their critical and constructive feedback to those who answered our call. We would also like to thank Professor Robert Stebbins who, having seen the call, kindly offered to produce an introductory preface. Most of all, however, we would like to thank the creators of, and contributors to, the interesting and insightful learnings found within each of the six submissions.

The six papers encapsulated within this special edition showcase the range of qualitative methods that can be adopted to explore occupational devotion and lifestyle entrepreneurship. The methods and methodologies range from the autobiographical to the analytical. The perspectives range from the well-being benefits for lifestyle entrepreneurs to the importance of occupational devotion beyond our paid careers. The parallel career paths of volunteers who become professionals and the social ambiguity associated with being a professional in a leisure pursuit are also introduced.

Collectively the papers provide a great conversation starter, showcasing the wide range of possibilities in this emerging area of creative leisure studies. Zoe Russell, Samantha Punch and Ian McIntosh, for example, explore how the professionalisation of bridge has blurred the line between work and leisure. This paper uses an 
insider researcher perspective from one of the authors and a series of qualitative interviews to explore an issue that is surely common to many leisure pursuits that have been professionalised: how do devotees in this elite version of the game deal with the internal tension between doing what they love and the perceived stigma of not having a 'proper job'?

By contrast, Alun David Morgan, Sue Langford and Tara Vassallo have provided an exploratory study of the career trajectories of sail trainers who begin their careers as volunteer leisure participants. Their research focusses on individuals who provide youth training on larger sailing vessels run by charitable trusts and they do so by exploring four parallel 'careers': occupational; serious leisure; sailing, and; sail training. Next, in their paper on lifestyle entrepreneurship, Kirstin Hallmann, Laura Bogner, Kathrin Sander and Konrad Reuß come together to explore how thirteen individuals from a range of sports have developed businesses that reflect their devotion to their profession. The thematic analysis highlights a number of themes connected to well-being.

Sandra Hirst and Carole-Lynne LeNavenec provide an autobiographical insight into their retirement from a career in nursing education. They explore the importance of extending their 'career' by continuing their intellectual engagement with the learning community they had been devoted to throughout their (paid) working lives. The paper uses their editorial roles for a peer-reviewed student journal to explore these themes. Similarly, Sue Stuart has produced an (auto)ethnographic case study that documents the author's evolutionary path from full-time teaching and management to lifestyle entrepreneurship as an exercise instructor for older adults. Much like our editorial, Stuart's uses Creative Analytical Practice to show how serious leisure is allied to the concept of ageing well, inviting the audience to draw answers from their own experience. Attention is especially drawn to periods of life transition, for example retirement or confinement due to COVID-19.

Finally, Miraíra Noal Manfroi, Rafael Morais Chiaravalloti and Alcyane Marinho bring together the auto-ethnographic narratives from two occupational devotees who share a passion for studying a remote biome located in the centralwest region of Brazil. Miraíra's background is in Physical Education, having studied leisure, children and games. Rafael is a Biologist who studies large mammals and local livelihoods. Having found themselves travelling in the same direction, within the same boat, the two scholars were able to produce something that has to be seen to be believed. Without giving anything away, it's a love(ly) story to which both RM and RKW were able to relate and enjoy. Their journey of self-discovery compliments that shared within this editorial and offers the perfect conclusion to what we hope will be special edition that inspires many more stories.

The issue begins with an introductory foreword from Bob Stebbins on the theoretical underpinnings of occupational devotion. We'd like to leave you with a quote RKW found in the fictional narrative that inspired one of his favourite movies; Field of Dreams. Kinsella (1982) cites that the difference between achieving success and obtaining happiness in quite simple; success is getting what you want, whereas happiness is wanting what you get. The end. 


\section{References}

Duffy, R. D., Dik, B. J., Douglass, R. P., England, J. W., \& Velez, B. L. (2018). Work as a calling: A theoretical model. Journal of Counseling Psychology, 65(4), 423-439. https://doi.org/10.1037/cou00 00276

Green, C. B., \& Jones, I. (2005). Serious Leisure, Social Identity and Sport Tourism. Sport in Society, 8(2), 164-181. https://doi.org/10.1080/174304305001102010

Kinsella, W. P. (1982). Shoeless Joe. Houghton.

Mitchell, R., Williams, M., \& Woodhouse, A. (2020). Transforming culinary arts education: Transformative approaches to recognition of prior learning. In CAUTHE 2020: 20: 20 Vision: New Perspectives on the Diversity of Hospitality, Tourism and Events (pp. 575-578). New Zealand: Auckland University of Technology Auckland.

Stebbins, R. A. (2004). Between work and leisure: The common ground of two separate worlds. Routledge.

Wright, R. K. (2017). Looking back (and forth): Acknowledging the people who make personal narratives plausible. Sport Management Review, 20(1), 81-91.

Wright, R. K. (2019). 'All the lonely people': Embracing autoethnographic creative analytical practice at the 2017 World Masters Games. Annals of Leisure Research, 22(3), 342-361.

Wright, R. K., \& Wiersma, C. (2019). "It pays to play": the emergence of innovative planning, occupational devotion and lifestyle entrepreneurship in Aotearoa/New Zealand. In V. Ratten (Ed.), Sport Entrepreneurship and Public Policy: Building a New Approach to Policy. London: Springer Press.

Publisher's Note Springer Nature remains neutral with regard to jurisdictional claims in published maps and institutional affiliations. 